\title{
Pengaruh Komposisi Media Pertumbuhan Terhadap Produksi Scleroglucan Pada Fermentasi Aerob Sclerotium rolfsii InaCC F-05
}

\author{
Bintang Iwhan Moehady ${ }^{1}$, Nancy Siti Djenar ${ }^{2}$ \\ ${ }^{1}$ Teknik Kimia, Jurusan Teknik Kimia, Politeknik Negeri Bandung \\ ${ }^{2}$ Analis Kimia, Jurusan Teknik Kimia, Politeknik Negeri Bandung \\ Email: nancysitidjenar@yahoo.com
}

\begin{abstract}
ABSTRAK
Scleroglucan adalah Eksopolisakarida yang dihasilkan dari fermentasi jamur Sclerotium rolfsii (S.rolfsii) dan telah digunakan di berbagai negara maju sebagai bahan pengental, industri makanan, farmasi, minyak dan industri lainnya. Berdasarkan hasil pengujian pada hewan tikus dalam jangka pendek dan panjang, scleroglucan tidak bersifat toksik dan tidak menunjukkan efek samping yang signifikan. Di Indonesia scleroglucan ini belum dikenal, lain halnya dengan jamur S. rolfsii yang lebih dikenal sebagai salah satu jamur patogen yang menyebabkan beberapa penyakit pada tanaman. Penyakit yang dihasikan oleh S.rolfsii merupakan penyakit potensial khususnya pada tanaman kedelai karena bila terserang akan mati serta patogen dan dapat bertahan lama di dalam tanah dalam bentuk sklerotia. Sehingga berbagai penelitian yang telah dilakukan di Indonesia hanya terbatas pada pencegahan, pengendalian dan karakterisasi dalam mengurangi sifat patogen dari $S$. rolfsii tersebut. Tujuan penelitian ini adalah menentukan komposisi media pertumbuhan S. Rolfsii InaCC F-05 untuk menghasilkan scleroglucan menggunakan substrat hidrolisat tepung tapioka. Dalam penelitian ini scleroglucan dibuat dalam media PDB dan media PDB termodifikasi yang masing masing menggunakan substrat dari gula cair $7 \%$ pada $28^{\circ} \mathrm{C}, \mathrm{pH} 5$, pengadukan $180 \mathrm{rpm}$ dengan waktu fermentasi S.rolfsii masing masing 46 dan 68 jam secara aerob. Hasil analisis FTIR menunjukkan bahwa scleroglucan hasil penelitian mempunyai puncak serapan pada 3408, 2933, 1633, 1408 dan 1031- $1151 \mathrm{~cm}^{-1}$. Puncak puncak serapan ini secara kualitatif telah sesuai dengan puncak serapan scleroglucan pada literatur. Secara keseluruhan dapat disebutkan bahwa S. rolfsii yang ditumbuhkan dalam media PDB termodifikasi dengan menggunakan substrat gula cair 7\% telah berhasil memproduksi scleroglucan dengan yield dan konversi tertinggi masing masing sebesar 15,0805 g/L dan 21,5400\%. Scleroglucan yang diperoleh mempunyai viskositas 1,9358 - 3,6579 cP. Nilai ini sudah memenuhi kriteria untuk dijadikan bahan campuran pada industri kimia.
\end{abstract}

Kata kunci : S.rolfsii, scleroglucan, fermentasi.

\section{ABSTACT}

Scleroglucan is an Exopolisaccharide produced from the fermentation of Sclerotium rolfsii (S.rolfsii) and has been used in many developed countries as a thickener, food, pharmaceutical, oil and other industries. Based on the results of tests on rats in the short and long term, it was found that scleroglucan is not toxic and have not shown significantly side effects. Scleroglucan is not well known in Indonesia, unlike fungus S. rolfsii which is better known as one of the pathogenic fungi that causes diseases in plants, especially in soybean crops where it will die and the pathogen can survive for a long time in the ground in the form of sclerotia. This is why the various studies that have been conducted in Indonesia are limited to prevention, control, and characterization in reducing the pathogenic of $S$. rolfsii. The objective of this study was to determine the growth media composition of S. Rolfsii InaCC F05 to produce scleroglucan using tapioca starch hydrolysate substrate. In this study scleroglucan was made in $P D B$ and modified $P D B$ media, each using a substrate of $7 \%$ liquid sugar at $28^{\circ} C, p H 5$, stirred at $180 \mathrm{rpm}$ with fermentation time of 46 and 68 hours in aerobic method. Based on FT-IR analysis showed that scleroglucan of this study had an absorption peak at 3408, 2933, 1633, 1408 and 1031 to $1151 \mathrm{~cm}^{-1}$. This absorption peak corresponds to the peak of scleroglucan uptake in the literature. Overall it can be concluded that $S$. rolfsii grown in modified PDB medium using a 7\% liquid sugar substrate has succeeded in producing scleroglucan with the highest yield and conversion of $15.0805 \mathrm{~g} / \mathrm{L}$ and $21.5400 \%$ respectively. The obtained scleroglucan has a viscosity of $1.9358-3.6579$ $c P$. These value has met the criteria in the chemical industry.

Keywords: S.rolfsii, scleroglucan, fermentation. 


\section{PENDAHULUAN}

Keberadaan jamur Sclerotium rolfsii (S.rolfsii) di Indonesia dinilai sebagai sebuah masalah karena sifatnya yang merugikan tanaman. Semangun (1991) mengemukakan bahwa penyakit oleh S.rolfsii merupakan penyakit potensial pada tanaman kedelai karena tanaman yang terserang akan mati. Sifat patogennya dapat bertahan lama di dalam tanah dalam bentuk sklerotia. Kehilangan produksi tanaman yang disebabkan S.rolfsii dapat mencapai 30\%. Kerugian ini sering terjadi pada lahan-lahan yang selalu ditanami tanaman kedelai dan kacang-kacangan lainnya (Wiryadiputra,2007). Sehingga berbagai penelitian yang telah dilakukan mengenai jamur tersebut hanya terbatas pada pencegahan, pengendalian dan karakterisasi dalam mengurangi sifat patogen dari S. rolfsii( Anisa dkk,2011; Prasetyoningrum dkk, 2012; Pudjihartati dkk, 2007).

Namun demikian, menurut Survase et al (2007), negara maju seperti Perancis terus mengembangkan S.rolfsii karena perannya yang dapat memproduksi gum sebagai bahan pengental makanan hingga EOR (Enhanced Oil Recovery) pada industri minyak bumi. S.rolfsii dinilai dapat menghasilkan suatu gum setelah melalui proses fermentasi. Gum yang dihasilkan oleh jamur ini disebut scleroglucan. Scleroglucan pada industri minyak berperan sebagai oil mud thickener, pada industri farmasi sebagai pelapis tablet, serta perannya sebagai formula dari ceramic glazes, integrated circuit chips, dan tinta. Pada bidang pertanian, scleroglucan berperan sebagai campuran pada pestisida dan pelindung bibit. Berbagai macam penelitian di negara maju menyebutkan scleroglucan terus dikembangkan hingga dikomersilkan oleh CECA S.E (Perancis) dengan nama Biopolimer CS dan Sanofi Bio Industries, juga pada perusahaan bumbu makanan Degussa (Jerman).

Berdasarkan hasil pengujian pada hewan tikus dalam jangka pendek dan panjang, scleroglucan tidak bersifat toksik dan tidak menunjukkan efek samping yang signifikan/sensitisasi (Survase, S.A., et al. 2007).

Sifat dan karakteristik scleroglucan mempunyai kesamaan dengan xanthan gum, perbedaannya adalah di Indonesia scleroglucan ini belum dikenal, sedangkan xanthan gum sudah banyak digunakan walaupun masih harus diimpor.

Struktur repeating unit dari scleroglucan ditunjukkan pada Gambar 1 berikut ini,

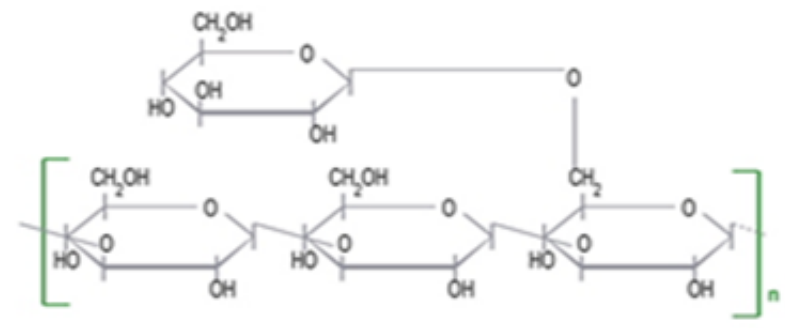

Gambar 1. Struktur repeating unit dari scleroglucan (Jochen. S. et al, 2011)

Struktur scleroglucan terdiri dari rantai lurus unit B-D-1(1-3)-glukopyranosyl dan mengandung cabang ß-D-1(1-6)-glukopyranosyl pada setiap unit ke tiga dari ß-D-1(1-3)-glukopyranosyl.

Sebagai upaya untuk mengubah paradigma negatif seperti yang disebutkan di atas dan mengembangkan peran S.rolfsii pada industri-industri di Indonesia, Moehady, B.I dkk (2016) telah melakukan penelitian dan menyebutkan bahwa bahan baku gula cair dapat menghasilkan scleroglucan melalui fermentasi $S$. rolfsii pada kondisi operasi tertentu. 
Berdasarkan hal di atas maka tujuan penelitian ini adalah mempelajari pengaruh komposisi media pertumbuhan dan kondisi fermentasi $S$. Rolfsii InaCC F-05 untuk menghasilkan scleroglucan menggunakan bahan baku hidrolisat tepung tapioka yaitu gula cair.

Hasil penelitian ini diharapkan mampu menjadi suatu inovasi baru bagi industri di Indonesia untuk memanfaatkan S.rolfsii yang saat ini keberadaannya. masih dinilai merugikan.

\section{METODE PENELITIAN}

Tahap awal penelitian ini adalah meregenerasi S.rolfsii di dalam media Potato Dextrose Agar (PDA) dan PDA termodifikasi dengan metode agar miring (slant agar) secara aseptik. Dalam tahap ini dilakukan variasi sumber N dan C. Selanjutnya S.rolfsii diinkubasi pada suhu $28^{\circ} \mathrm{C}$ selama 5 hari di dalam inkubator. Pengamatan dilakukan untuk memeriksa kemungkinan terjadinya kontaminasi.

Kultur S.rolfsii hasil regenerasi dimasukkan ke dalam labu erlenmeyer yang telah mengandung $50 \mathrm{ml}$ Potatoes Dextrose Broth ( PDB) dengan cara penggesekan secara aseptik. Selanjutnya media ini diinokulasi pada suhu $28^{\circ} \mathrm{C}, 150 \mathrm{rpm}$ selama 48 jam didalam shaker incubator. Hasil dari inokulasi ini adalah inokulum aktif dari S.rolfsii dengan jumlah selnya yang meningkat (CFU).

Inokulum aktif dimasukkan kedalam media PDB dan media PDB termodifikasi untuk membuat kurva pertumbuhan S.rolfsii. Pengambilan data berat sel kering dilakukan pada waktu tertentu (sampling) selama masa pertumbuhan. Selanjutnya menentukan laju pertumbuhan maksimum S.rolfsii. Data ini selanjutnya akan digunakan untuk proses produksi scleroglucan.

Produksi scleroglucan dilakukan dengan cara fermentasi aerob secara batch pada suhu $28^{\circ} \mathrm{C}$, $\mathrm{pH} 5,180$ rpm. Untuk melihat pengaruh komposisi media pertumbuhan terhadap karakter scleroglucan, maka digunakan dua jenis media yaitu PDB dan PDB termodifikasi yang masing masing telah ditambahkan dengan substrat gula cair $7 \%$.

Setelah fermentasi dihentikan maka pada media produksi dilakukan pasteurisasi pada suhu $90^{\circ} \mathrm{C}$ selama 15 menit dengan tujuan untuk mematikan S.rolfsii. Pemurnian produk terdiri dari pemisahan cairan fermentasi dari sel S.rolfsii dengan cara sentrifugasi selama 30 menit, pengadukan $2000 \mathrm{rpm}$. Supernatan yang diperoleh merupakan produk scleroglucan. Untuk memperoleh scleroglucan dalam bentuk padatan maka ke dalam supernatan ditambahkan pelarut organik IPA (Iso Propil Alkohol) sebanyak 3x volume supernatan. Kemudian didiamkan selama 1 x 24 jam pada suhu $4^{\circ} \mathrm{C}$ dan menghasilkan scleroglucan dalam bentuk endapan. Setelah disaring, endapan dikeringkan di dalam oven vakum pada suhu ruang dan pengeringan dilanjutkan pada suhu $\pm 30^{\circ} \mathrm{C}$ hingga diperoleh scleroglucan dalam bentuk serbuk. Selanjutnya ditentukan yield, rendemen, viskositas serta analisis gugus fungsi scleroglucan menggunakan FTIR. Rancangan Penelitian ditunjukkan pada Gambar 2 berikut ini` 


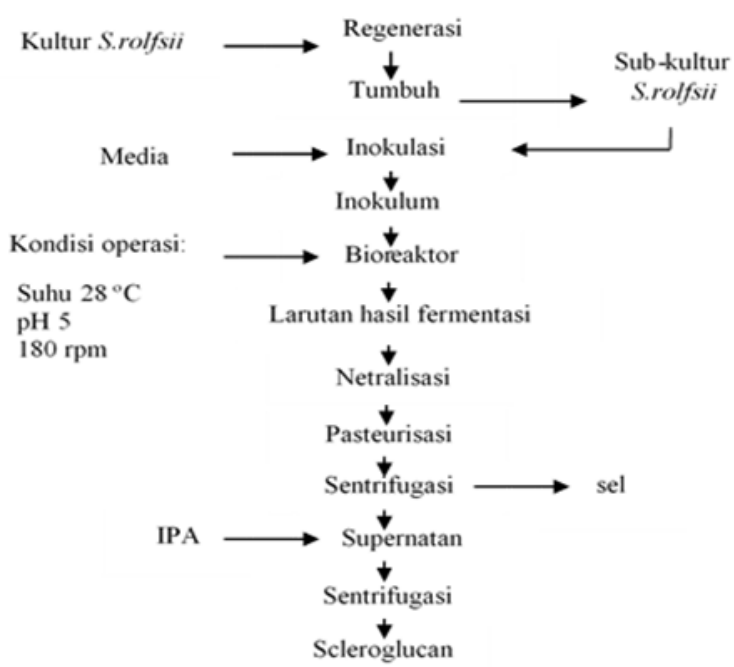

Gambar 2. Rancangan produksi scleroglucan

\section{HASIL DAN PEMBAHASAN}

Regenerasi S.rolfsii dilakukan pada media agar miring dan cawan petri dengan dua variasi media yaitu PDA (Potato Dextrose Agar) dan PDA termodifikasi yang mengandung $\mathrm{K}_{2} \mathrm{HPO}_{4}$ dan $\mathrm{KH}_{2} \mathrm{PO}_{4}$ sebagai buffer dan yeast extract sumber nitrogen organik, yang keduanya dapat meningkatkan jum;ah sel S.rolfsii.

Tahap inokulasi bertujuan untuk menumbuhkan dan mengaktivasi sel ke media cair PDB dari media padat PDA.Pada inokulasi ini, suhu dipertahankan pada $28{ }^{\circ} \mathrm{C}$. Suhu di bawah $28{ }^{\circ} \mathrm{C}$, akan menghasilkan produk samping berupa asam oksalat. Terbentuknya asam oksalat akan mengakibatkan turunnya $\mathrm{pH}$ media dan mengganggu pertumbuhan $S$. rolfsii. Dalam Inokulum aktif terjadi peningkatan jumlah sel yang meningkat, larutan menjadi pekat dan tumbuhnya gumpalan putih (miselium).

Pembuatan kurva pertumbuhan bertujuan untuk menentukan waktu $S$. rolfsii saat mengalami fase eksponensial sehingga laju pertumbuhan maksimum $S$. rolfsii dapat ditentukan. Kurva pertumbuhan $S$. rolfsii dalam media PDB dan PDB termodifikasi disajikan berturut-turut pada gambar 3 dan gambar 4 . berikut ini,

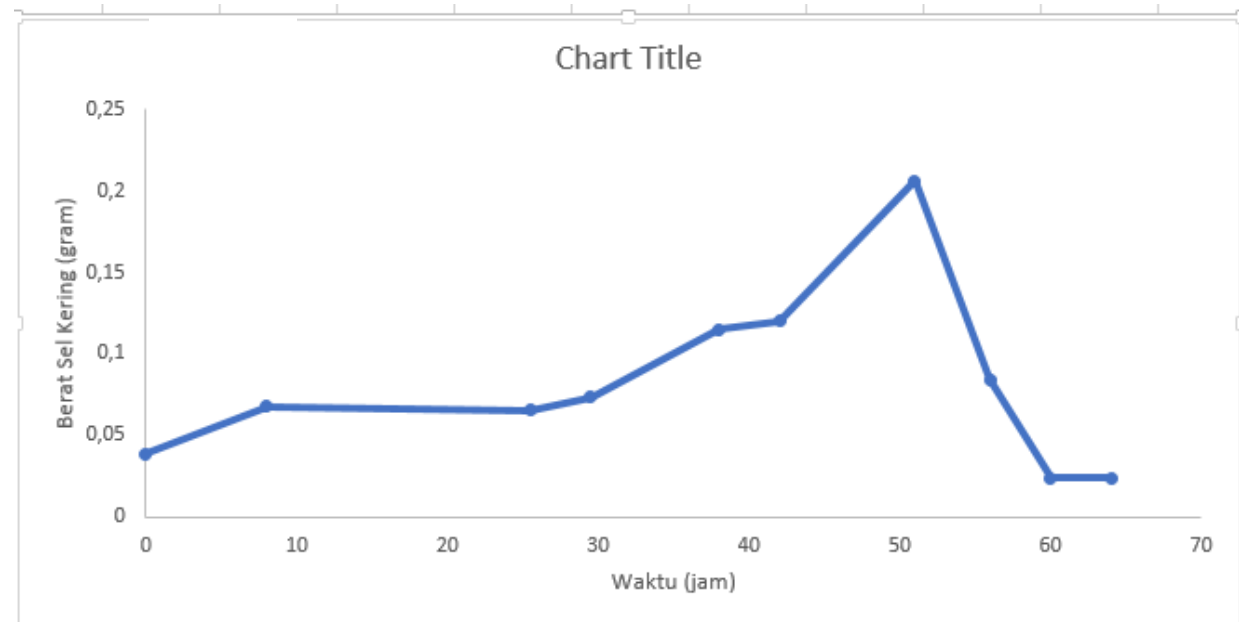

Gambar 3. Kurva pertumbuhan S. rolfsii pada PDB 


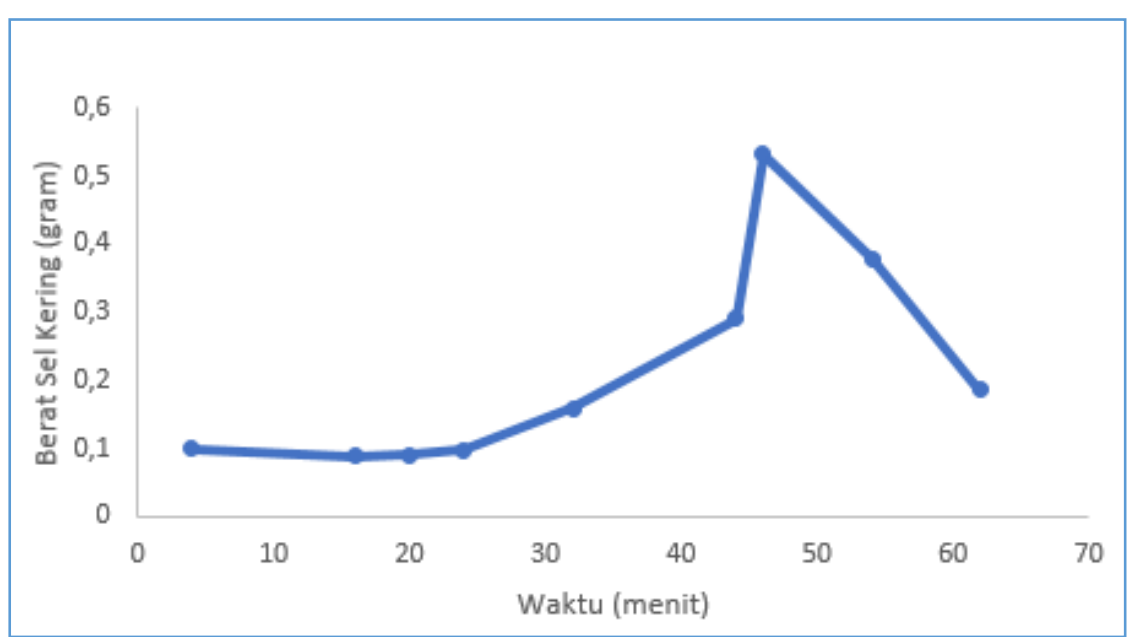

Gambar 4. Kurva pertumbuhan $S$. rolfsii pada PDB termodifikasi

Pada gambar 3 dan gambar 4, terlihat adanya peningkatan pertumbuhan sel $S$. rolfsii seiring bertambahnya waktu. Saat terjadi peningkatan jumlah sel yang cukup signifikan, S.rolfsii sedang dalam keadaan fasa eksponensial. Hal ini menunjukkan bahwa komposisi pada PDB maupun PDB termodifikasi sesuai dengan komposisi yang dibutuhkan untuk pertumbuhan $S$. rolfsii.

Pada Gambar 3 diperoleh fasa eksponensialnya terjadi pada rentang waktu 34-47 jam dengan laju pertumbuhan maksimum $S$. rolfsii adalah 0,015 gram/jam pada jam ke-46. Pada Gambar 4 diperoleh fasa eksponensialnya pada rentang 32-44 jam dengan laju pertumbuhan sel maksimum adalah 0,0267 gram/jam pada jam ke-43.

Waktu yang diperoleh dari ke dua kurva pertumbuhan tersebut akan menjadi acuan untuk memindahkan starter ke media produksi.

Untuk menentukan lamanya waktu produksi scleroglucan dengan tepat, maka dilakukan sampling setiap 4 jam pada media PDB dan PDB termodifikasi yang masing masing telah ditambahkan dengan substrat gula cair $7 \%$, seperti yang disajikan pada gambar 5 berikut ini,

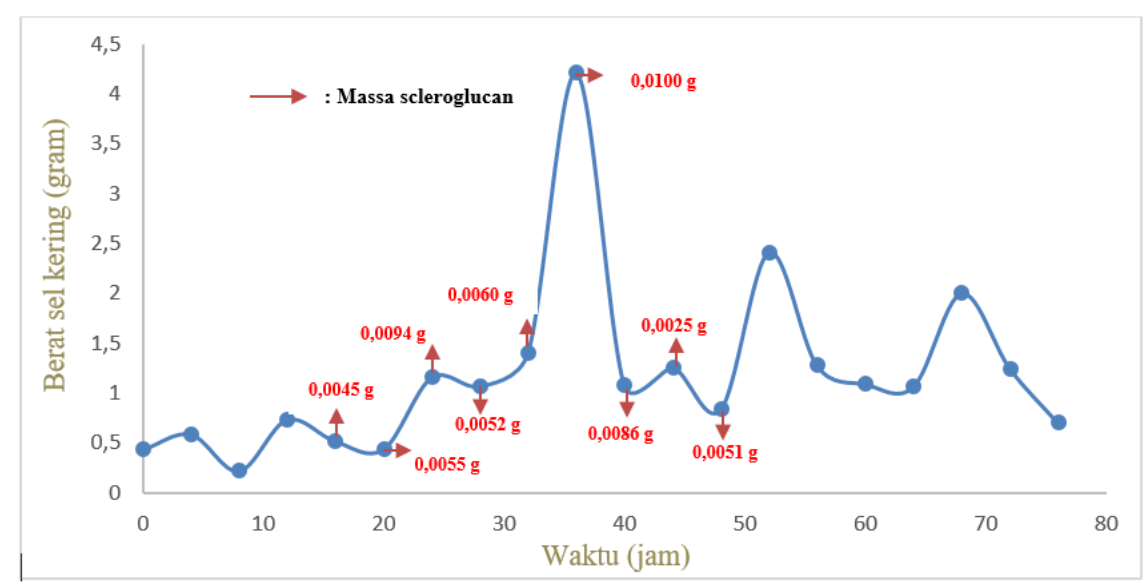

Gambar 5. Kurva produksi scleroglucan pada PDB dengan substrat gula cair 7\% 
Pada Gambar 5. dapat ditunjukkan bahwa scleroglucan mulai terbentuk pada jam ke-16 dengan berat 0,0045 gram. Produksi scleroglucan tertinggi diperoleh pada jam ke-36 dengan berat 0,01 gram. Hal ini menunjukkan bahwa fasa stasioner terjadi ketika fermentasi berlangsung selama 36 jam sehingga fermentasi dihentikan pada fasa kematian yaitu pada jam ke-46. Selain itu perolehan scleroglucan sudah rendah sekali, $\mathrm{pH}$ fermentasi telah mengalami penurunan hingga 3,3. Hal ini dapat mengganggu proses produksi scleroglucan.

Kurva produksi scleroglucan untuk S.rolfsii yang ditumbuhkan pada media PDB termodifikasi yang ditambahkan dengan substrat gula cair 7\%, dapat ditunjukkan pada gambar 6. berikut ini,

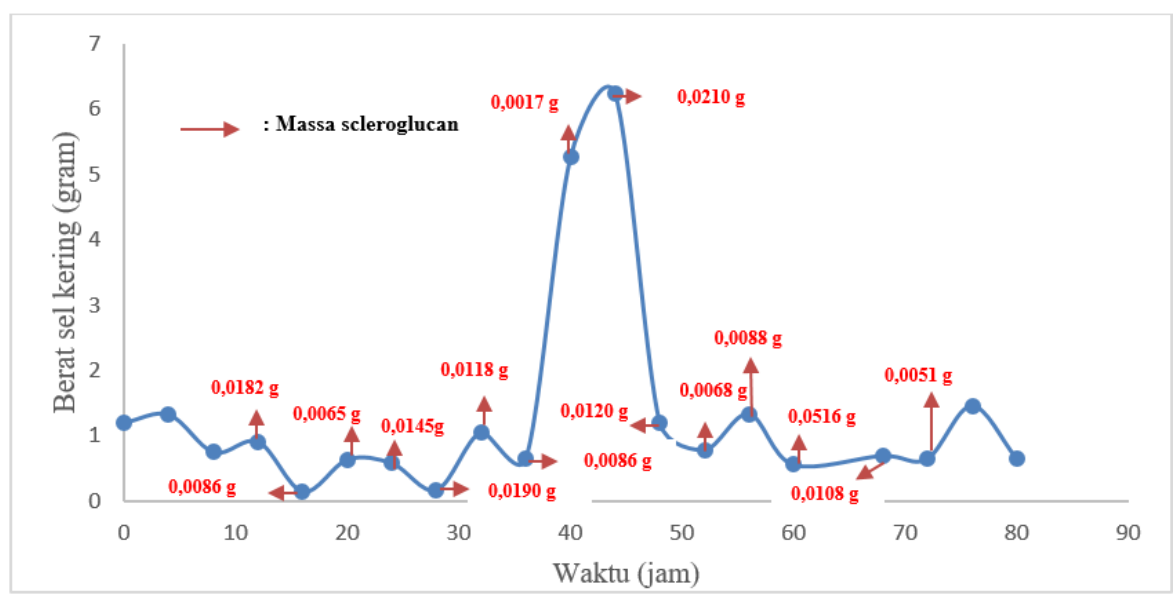

Gambar 6. Kurva produksi scleroglucan pada PDB termodifikasi dengan substrat gula cair 7\%

Dalam kurva tersebut scleroglucan mulai terbentuk pada jam ke-12 yaitu 0,0182 gram. Produksi scleroglucan tertinggi terjadi pada waktu ke-60 dengan berat 0,0516 gram. Fasa stasioner terjadi ketika fermentasi berlangsung selama 60 jam sehingga fermentasi dihentikan pada fase kematian yaitu pada jam ke 68. Perbedaan berat scleroglucan pada ke dua disebabkan adanya komposisi yang berbeda antara PDB dan PDB termodifikasi. Pada PDB termodifikasi terdapat yeast extract sebagai sumber nitrogen organik yang berperan sebagai faktor pertumbuhan (growth factor) pada metabolisme S.rolfsii. Selain itu pada PDB termodifikasi mengandung $\mathrm{KH}_{2} \mathrm{PO}_{4}$ dan $\mathrm{K}_{2} \mathrm{HPO}_{4}$ yang berperan sebagai buffer yang dapat mempertahankan $\mathrm{pH}$ media produksi sehingga produksi scleroglucan dapat berjalan dengan baik.

Hasil penelitian Farina et al (2009) waktu produksi scleroglucan selama 48 dan 72 jam dengan kondisi proses seperti suhu, agitasi, dan $\mathrm{pH}$ yang sama. Perbedaan waktu produksi ini disebabkan adanya perbedaan antara isolat S.rolfsii dengan substrat yang digunakan. Pada penelitian Farina et al (2009), isolat S.rolfsii yang digunakan yaitu ATCC 20126 dengan substrat sukrosa.

Tahap fermentasi yaitu tahap diproduksinya scleroglucan. Media pada fermentasi merupakan PDB dan PDB termodifikasi yang masing-masing telah ditambahkan dengan substrat gula cair 7\%. Pada tahap ini fermentasi dilakukan secara aerob. Oksigen disuplai dari udara yang ada dalam fermentor dengan perbandingan volume antara cairan fermentasi dengan fermentor adalah 1:5 (Stanbury P.F, 1998).

Scleroglucan yang dihasilkan dari fermentasi masih tercampur dengan selnya sehingga perlu dipisahkan. dengan cara sentrifugasi pada $4500 \mathrm{rpm}$, suhu $20{ }^{\circ} \mathrm{C}$ selama 30 menit. Supernatan yang diperoleh merupakan produk scleroglucan, sedangkan sel S. rolfsii dikeringkan untuk memperoleh berat sel keringmya. Selanjunya supernatan ditambahkan dengan pelarut IPA (Isopropil Alkohol) 
dengan perbandingan 1:3(v/v) dan di diamkan selama 24 jam pada suhu $8{ }^{\circ} \mathrm{C}$ untuk mengendapkan scleroglucan. Untuk memperoleh scleroglucan dalam bentuk serbuk maka dilakukan pengeringan.

Dalam penelitian ini dipilih IPA sebagai pelarut karena bersifat polar sehingga mampu menurunkan afinitas air terhadap scleroglucan dan mampu pengotor seperti zat warna, garam, dan sel. (F. GarciaOchoa, 2000). Secara kimia, IPA memiliki permitivitas ( $(\varepsilon)$ yang lebih kecil dibandingkan dengan pelarut lain seperti etanol dan aseton (IPA: 18, aseton: 21, etanol: 20). Menurut Tinoco 2013, semakin rendah permitivitas suatu pelarut, semakin mudah pelarut tersebut bercampur dengan pelarut lainnya karena memiliki kepolaran yang lebih besar. Dengan demikian jumlah IPA yang diperlukan pada pemurnian scleroglucan, lebih rendah dibandingkan dengan pelarut lain seperti etanol dan aseton. Menurut F. Garcia-Ochoa (2000), untuk menghasilkan presipitasi eksopolisakarida hingga 100\%, maka perbandingan IPA dengan reagent-nya adalah 3:1 (v/v), sedangkan untuk aseton 4:1(v/v) dan etanol 6:1 (v/v). Dalam hal ini terlihat bahwa IPA lebih mampu menurunkan kelarutan dan memisahkan eksopolisakarida dari pengotornya. Selain itu, penambahan IPA dengan perbandingan 3:1 $(\mathrm{v} / \mathrm{v})$ merupakan pilihan paling baik pula untuk penghematan proses pemurnian eksopolisakarida.

Perolehan scleroglucan pada fermentasi S. rolfsii ditunjukkan pada Tabel 1 dan 2 berikut ini.

Tabel 1. Yield Scleroglucan Pada Fermentasi S.rolfsii menggunakan substrat gula cair 7\%

\begin{tabular}{|l|l|l|l|}
\hline No & $\begin{array}{l}\text { Komposisi } \\
\text { Media } \\
\text { Pertumbuhan }\end{array}$ & $\begin{array}{l}\text { Berat } \\
\text { Sel } \\
\text { Kering } \\
\text { (g/L) }\end{array}$ & $\begin{array}{l}\text { Yield } \\
\text { Scleroglucan } \\
\text { (g/L) }\end{array}$ \\
\hline 1 & PDB & 3,3685 & 1,4460 \\
\hline 2 & $\begin{array}{l}\text { PDB } \\
\text { termodifikasi }\end{array}$ & 11,8945 & 15,0805 \\
\hline
\end{tabular}

Dari tabel 1. dapat dilihat bahwa perolehan berat kering sel dan yield tertinggi ada pada media PDB termodifikasi, masing masing mencapai $71,68 \%$ dan $90,41 \%$. Hal ini menunjukkan bahwa penambahan yeast extract selain akan meningkatkan petumbuhan sel juga sebagai sumber nitrogen organik yang meningkatkan produktivitas S.rolfsii dalam menghasilkan enzim untuk mengonversi substrat gula cair menjadi scleroglucan. Penambahan $\mathrm{K}_{2} \mathrm{HPO}_{4}$ dan $\mathrm{KH}_{2} \mathrm{PO}_{4}$ sebagai buffer akan mempertahankan $\mathrm{pH}$ media produksi yaitu pada $\mathrm{pH} 5$ sebagai $\mathrm{pH}$ optimum pada produksi scleroglucan. (Bhagat, 2011).

Tabel 2. \% Konversi dan Viskositas Scleroglucan Pada Fermentasi S.rolfsii menggunakan substrat gula cair 7\%

\begin{tabular}{|c|c|c|c|}
\hline No & $\begin{array}{c}\text { Komposisi } \\
\text { Media } \\
\text { Pertumbuhan }\end{array}$ & $\begin{array}{c}\text { Konversi } \\
(\mathbf{\%})\end{array}$ & $\begin{array}{c}\text { Viskositas } \\
(\mathbf{c P})\left(\mathbf{2 6}^{\mathbf{0}} \mathbf{C}\right)\end{array}$ \\
\hline 1 & PDB & 2,0660 & 1,9358 \\
\hline 2 & $\begin{array}{c}\text { PDB } \\
\text { termodifiasi }\end{array}$ & 21,5400 & 3,6579 \\
\hline
\end{tabular}


Konversi tertinggi dari hasil produksi scleroglucan yaitu 21,54 \% yakni pada PDB termodifikasi dengan substrat gula cair 7\% Hasil tersebut masih belum memenuhi kriteria konversi pada skala industri yaitu lebih dari 50\% (Palennari dan Rante, 2009). Dalam hal ini sebagian substrat gula cair digunakan untuk menunjang pertumbuhan S.rolfsii. Untuk organisme aerobik, khususnya jamur, oksigen berperan cukup penting dalam banyak aspek metabolisme intraseluler. Keberadaan oksigen terlarut akan berpengaruh pada laju repirasi, sintesis dan aktivitas enzim, pembentukan metabolit dan lain lain. Dalam hal ini penggunaan laju aerasi dan agitasi yang optimum dapat mengontrol pertumbuhan sel dan produksi scleroglucan. Ke dua parameter ini berhubungan erat dengan kultur sel, massa sel dan laju perpindahan panas dimana akan meningkatkan transfer nutrien dan oksigen dari cairan fermentasi menuju sel. Selain itu dapat mengatur laju metabolit ( scleroglucan, produk samping dan $\mathrm{CO}_{2}$ ) dari dalam sel menuju media fermentasi (Castillo A. $\mathrm{N}$ et al., 2015). Dalam penelitian ini fermentasi dilakukan dalam skala laboratorium dimana kebutuhan oksigen hanya disuplai dari udara yang ada dalam bioreaktor, tidak dilengkapi dengan aerator. Sedangkan agitasi hanya menggunakan shaker incubator tidak menggunakan alat pengaduk khusus.

Viskositas scleroglucan yang diperoleh pada hasil penelitian ini adalah 1,9358 - 3,6579 cP. Nilai viskosias scleroglucan dapat menentukan aplikasi scleroglucan di industri. Scleroglucan dengan viskositas 1,5-3 mPa.s (cP) dapat diaplikasikan untuk bahan campuran pasta gigi dan obat kumur (Castillo A. N., et al, 2015). Dari hasil penelitian ini, viskositas scleroglucan tersebut sudah memenuhi kriteria untuk dijadikan bahan campuran pada industri kimia.

Berdasarkan hasil analisis FTIR menunjukkan bahwa fermentasi aerobik S.rolfsii menggunakan substrat gula cair 7\% secara kualitatif dapat menghasilkan scleroglucan seperti yang ditunjukkan dalam gambar 7 dan 8 . Dalam hal ini adanya kesesuaian gugus fungsi antara scleroglucan hasil penelitian dengan scleroglucan literatur (Casadei, M.A. et al, 2007; Farina, J.I, 2008) yaitu gugus OH pada $3408 \mathrm{~cm}^{-1}$, gugus $\mathrm{CH}$ stretching pada $2931-2933 \mathrm{~cm}^{-1}$, gugus $\mathrm{CH}$ bending pada $1404-1408 \mathrm{~cm}^{-1}$, Gugus CH 1624-1633 $\mathrm{cm}^{-1}$ dan gugus COC dan $\mathrm{COH}$ stretching pada $1076-1031 \mathrm{~cm}^{-1}$.

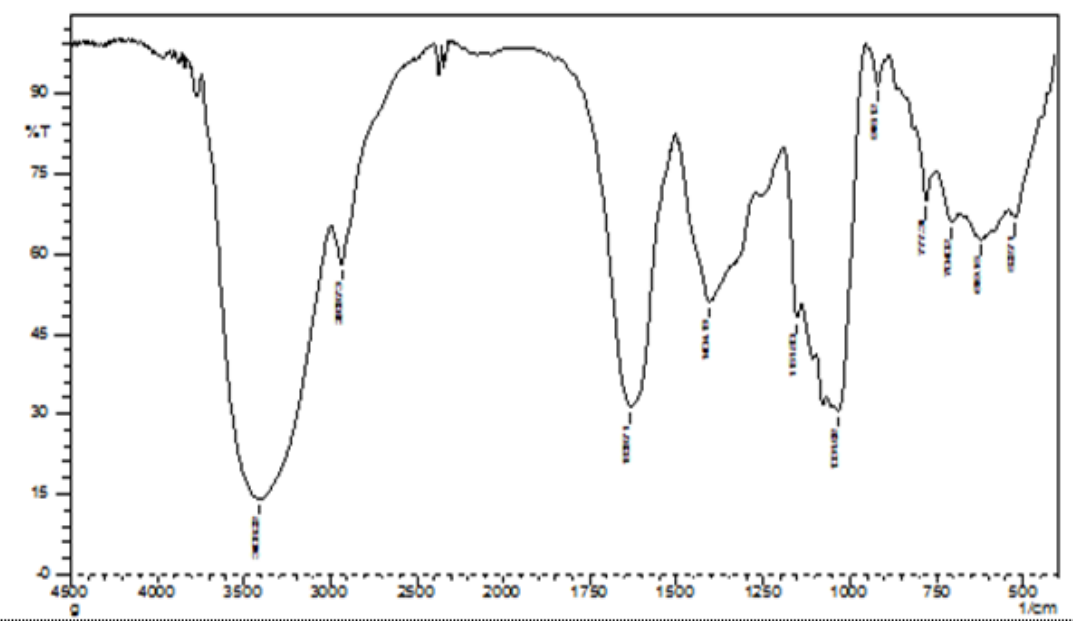

Gambar 7. Spektrum FTIR scleroglucan pada media PDB menggunakan substrat gula cair 7\% 


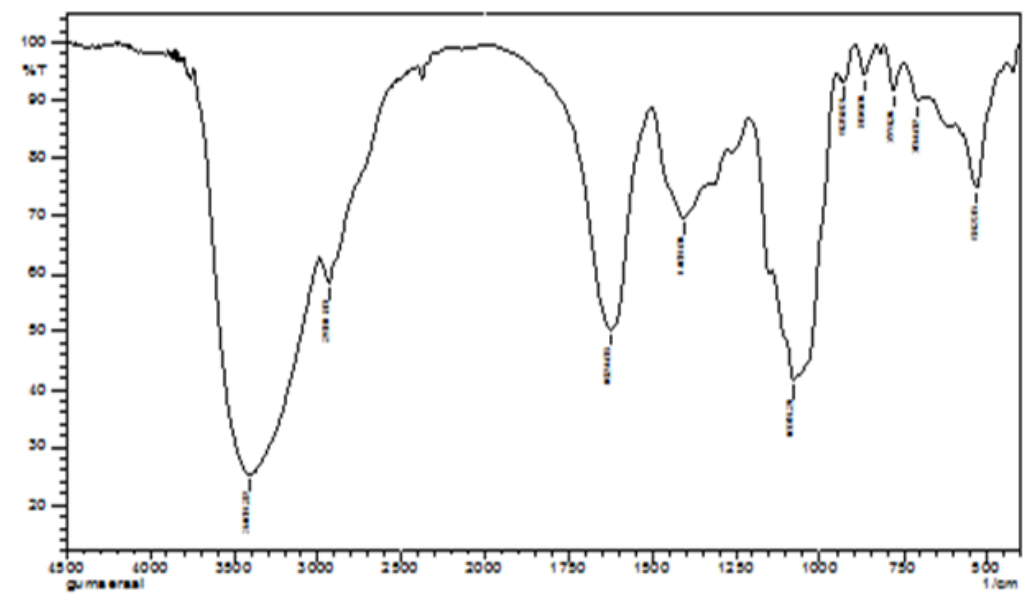

Gambar 8. Spektrum FTIR scleroglucan pada media PDB termodifikasi menggunakan substrat gula cair 7\%

Setiap scleroglucan dapat menunjukkan jumlah derajat percabangan $\beta$-1,6-glikosidik, berat molekul, jumlah dan panjang rantai tepi, serta derajat polimerisasi yang berbeda-beda. Hal tersebut tergantung pada jenis isolat $S$. rolfsii, strain, kondisi kultur atau kondisi proses yang digunakan. Perbedaan karakteristik tersebut akan menghasilkan scleroglucan dengan nilai viskositas.yang berbeda. Selanjutnya di industri akan dimanfaatkan untuk tujuan yang berbeda pula.

\section{KESIMPULAN}

Berdasarkan hasil analisis menggunakan FT-IR, S. rolfsii yang ditumbuhkan dalam media PDB termodifikasi menggunakan substrat gula cair $7 \%$ telah berhasil memproduksi scleroglucan dengan yield dan konversi tertinggi masing masing sebesar 15,0805 g/L dan 21,5400\%. Viskositas scleroglucan berkisar antara 1,9358 - 3,6579 cP. Nilai ini sudah memenuhi kriteria untuk dijadikan bahan campuran pada industri kimia.

\section{DAFTAR PUSTAKA}

[1] Anisa, Yana., dkk., 2011, Pengaruh mulsa dan PGPR terhadap insidensi penyakit busuk pangkal batang (S.rolfsii sacc) pada tanaman kedelai (Glycine $\max \mathrm{L}$ Merill).(Online).http://repository.ipb.ac.id/handle/123456789/53363.

[2] Bhagat, Indramani. 2011. Factors Influencing Mycelial Growth of Sclerotium rolfsii. Biratnagar: Department of Botany, Post Graduate Campus, Tribhun University, Nepal.

[3] Casadei M. A, et al. 2007. Physical Gels of Carboxymethyl Derivative of Scleroglucan: Synthesis and Characterization. Roma: Science Direct.

[4] Castillo Aletjandra .N. ; Farina, Julia I. 2015. Microbial production of scleroglucan and downstream processing. Frontiers In Microbiology.

[5] Farina J.I; Sineriz I; Molina O.E; Perotti N.I . 1998. High scleroglucan production by Sclerotium rolfsii: Influence of medium composition. Argentina.

[6] Farina J.I; Vinarta S.C; Cattaneo.M; Figueroa,L.I. 2009. Structural stability of Sclerotium rolfsii ATCC 201126 b-glucan with fermentation time : a chemical, infrared spectroscopic and enzymatic approach. J. Appl.Microbiol. 106, 221-232.doi:10.1111/j.1365-2672.2008. 03995.x. 
[7] Garcia-Ochoa, F, et al. 2000. Xanthan Gum : Production, Recovery, and Properties. Madrid: Biotechnology Advances 18 (2000) 549-579

[8] Jochen Schmid., et al 2011, Scleroglucan: Biosynthesis, production and Application of a versatile hydrocolloid, Appl Micobial Biotechnol, 91: 937-947.

[9] Moehady, B.I., dkk., 2016. Produksi Scleroglucan dari Sckerotium rolfsii Menggunakan Media Gula Cair Hasil Hidrolisis Pati Singkong. Yogyakarta: Prosiding Seminar Nasional Teknik Industri UGM.

[10] Palennari, Muhiddin dan Herlina Rante. 2009. Kajian Pembentukan Gum Xanthan dari Limbah Padat Sagu oleh Xanthomonas campetris. Makassar: Bionature Vol. 10 (1): Hlm: 24-28.

[11] Pudjihartati, E. 2007, Ketahanan kacang tanah dan tembakau terhadap infeksi S.rolfsii sacc dengan ekspresi kitinase tinggi. (Online). http://repository.ipb.ac.id/123456789/46579., Pusat Pelatihan Agrobisnis, Bioteknologi dan Sarana Industri.

[12] Semangun, Haryono. 1991. Penyakit-penyakit Tanaman Pangan di Indonesia. Yogyakarta: UGM.

[13] Stanbury, P. F, A. Whitaker, dan S. J. Hall. 1995. Principles of Fermentation Technology second ed. Hertfordshire, UK.

[14] Survase, Shrikan T A, et al. 2007. Scleroglucan : Fermentive Production, Downstream Processing and Applications. Mumbai: Food Engineering and Technology Department, Institute of Chemical Technology University of Mumbai.

[15] Wiryadiputra, S. 2007. Epidemi Penyakit Tumor Pada Sengon (Paraserianthes falcatria) di Jawa Timur, Indonesia. Jurnal Ilmu Kehutanan ., Vol.1 No.1. 